\title{
Differential Effects of Electroconvulsive Therapy in the Treatment of Major Depressive Disorder
}

\author{
Anna Stippl $^{\mathrm{a}}$ Fatma Nur Kirkgöze $^{\mathrm{a}}$ Malek Bajbouj $^{\mathrm{a}}$ Simone Grimm ${ }^{\mathrm{a}-\mathrm{c}}$ \\ a Department of Psychiatry and Psychotherapy, Charité, University Medicine Berlin, Campus Benjamin Franklin, \\ Berlin, Germany; ${ }^{\mathrm{b}} \mathrm{MSB}$ Medical School Berlin, Berlin, Germany; ${ }^{\mathrm{C} D e p a r t m e n t}$ of Psychiatry, Psychotherapy and \\ Psychosomatics, University of Zurich, Psychiatric Hospital, Zurich, Switzerland
}

\section{Keywords}

Electroconvulsive therapy - Major depressive disorder · Antidepressant efficacy · Neurobiological markers of ECT response

\begin{abstract}
Background/Aims/Methods: Electroconvulsive therapy (ECT) is still one of the most potent treatments in the acute phase of major depressive disorder (MDD) and particularly applied in patients considered treatment resistant. However, despite the frequent and widespread use of ECT for $>70$ years, the exact neurobiological mechanisms underlying its efficacy remain unclear. The present review aims to describe differential antidepressant and cognitive effects of ECT as well as effects on markers of neural activity and connectivity, neurochemistry, and inflammation that might underlie the treatment response and remission. Results: Region- specific changes in brain function and volume along with changes in concentrations of neurotransmitters and neuroinflammatory cytokines might serve as potential biomarkers for ECT outcomes. Conclusions: However, as current data is not consistent, future longitudinal investigations should combine modalities such as MRI, MR spectroscopy, and peripheral physiological measures to gain a deeper insight into interconnected time- and modality-specific changes in response to ECT.

๑) 2020 S. Karger AG, Basel
\end{abstract}

Major depressive disorder (MDD) is a highly prevalent psychiatric disorder that pervades all socioeconomic classes. As a leading cause of medical disability, it has a huge negative impact on public health and productivity $[1,2]$. In 2016, it ranked among the top 10 causes of medical conditions in all but 4 countries [3, 4]. Existing pharmacological therapies for MDD have a delayed onset of action and, even though standard antidepressant treatments are often effective, about $30 \%$ of patients suffering from MDD do not respond sufficiently to established pharmacological or psychotherapeutic treatments [5]. After nonresponse to 2 adequate treatments, a patient is described as having a treatment-resistant depression, which is associated with illness chronicity, a reduced quality of life, and a higher risk for suicide [6]. Especially for those patients, electroconvulsive therapy (ECT) is a recommended treatment strategy $[7,8]$. It has response rates of $60-80 \%$, making it one of the most potent and rapidly acting treatments for affective disorders [7].

During ECT, an electrical current is administered to the brain through the scalp, which provokes a therapeutic seizure. Usually, a series of ECTs (i.e., 9-12) is applied over several weeks [8]. ECT is effective in the treatment of uni- and bipolar depression but also other psychiatric disorders such as catatonia, mania, or schizophrenia [911]. Although international guidelines exist, there is no karger@karger.com

www.karger.com/nps

(C) 2020 S. Karger AG, Base

Karger"
Simone Grimm

Department of Psychiatry and Psychotherapy, Charité, Universitätsmedizin Berlin Hindenburgdamm 30 DE-12203 Berlin (Germany)

simone.grimm@charite.de 
uniform global utilization regarding ECT provision, which results in a high variability between different countries and regions [12]. A general decline in utilization is observable in America, whereas an increase seems to be occurring in China [13]. Regarding ECT administration in Western countries, the majority of patients are older women with MDD, whereas in Asian countries younger men with schizophrenia constitute the majority [12]. Here we will focus on a description of the differential effects of ECT that might underlie the treatment response and remission in MDD.

Despite the frequent and widespread use of ECT for $>70$ years, the exact neurobiological mechanisms underlying its efficacy remain unclear. It seems to exert its antidepressant effect through its impact on regional brain structure and function via different neurotransmitter systems, inflammatory processes, and neurogenesis [8]. In a broader sense, understanding the therapeutic effects of ECT may also shed more light on the pathophysiological causes of severe depression and the mechanisms of action of effective treatments, and it might be the fundament for approaches aimed at individualizing therapy strategies.

\section{Parameters Predicting and Influencing the Antidepressant ECT Response}

Investigations of clinical predictors of the ECT response have found that patients with depressive episode durations of $<1$ year or without a failed adequate antidepressant medication trial in the current episode most likely respond to ECT [14]. It has been suggested that ECT should be considered as the primary treatment strategy in special cases of depression requiring fast relief, such as severe psychotic depression and severe depression with psychomotor retardation, suicidality, or persistent food refusal [15]. Bipolar disorder, sex, age at onset, and the number of previous episodes were no significant predictors of response, whereas older age and psychotic features were weakly associated with a response to ECT. Additionally, it has been described that long-lasting mixed bipolar episodes and lifetime comorbidity with obsessive-compulsive disorder can predict a lack of response to ECT [16]. Increased ECT efficacy has mainly been observed in psychotic depression and patients who previously responded to ECT [17].

Specific epigenetic methylation patterns [18] and genotypes [19] might possibly predict the ECT response, although existing data exhibit large amounts of contradic- tions, requiring further investigations with larger sample sizes in order to draw final conclusions.

Although ECT is well tolerated and usually associated with improvement in patients' quality of life, functioning, and wellbeing, there are complaints about side effects such as cognitive deficits, headaches, and disorientation [20]. Particularly verbal episodic memory seems to be more disturbed by ECT than visual episodic memory. Processing speed, spatial problem solving, and global cognition demonstrate small impairments in comparison to baseline, while working memory does not seem to be affected. These cognitive deficits are mainly limited to the first 3 days after ECT and seem to be resolved within 2 weeks [21]. Accordingly, it has recently been confirmed that ECT does not lead to significant long-term memory impairments but rather to significant improvement 1 month after treatment, correlating with clinical improvement [22]. Thus, faced with the side effects of pharmacotherapy such as weight gain, sexual dysfunction, drug interactions, and discontinuation symptoms [23, 24], ECT has been proven to be beneficial not only due to the speed of recovery but also due to the short duration of the emerging side effects.

The efficacy and cognitive side effects of ECT seem to be influenced by parameters such as the positioning of electrodes, pulse width, and electrical dosage $[25,26]$. There is evidence that right unilateral ECT at a high dosage is as effective as bilateral ECT but is accompanied by less cognitive side effects. When comparing different stimulus intensities $(4 \times, 7 \times$, and $10 \times$ above the seizure threshold), higher-intensity dosages seem to be associated with more cognitive side effects. Lower stimulus intensities, such as $4 \times$ to $7 \times$, have demonstrated efficacies comparable to $10 \times$ without causing as many side effects [26]. A comparison of brief versus ultrabrief right unilateral ECT found the brief version to be more efficacious in terms of symptom reduction, simultaneously requiring fewer treatment sessions but leading to greater cognitive side effects [27].

Despite the relatively rapid and profound antidepressant effect of ECT in MDD, post-ECT relapse is frequent, especially if no maintenance treatment is supplied [28]. Since the relapse rates of ECT in patients with MDD amount to approximately 50\% after 6-12 months, maintenance treatment involving ECT or pharmacotherapy should be carefully chosen and adapted according to the individual history [29]. The combination of acute ECT and pharmacotherapy followed by the combination of ECT and medication as maintenance therapy in uni- and bipolar depression is associated with lower relapse rates 
than pharmacotherapy alone [30]. Recently, a third maintenance alternative in terms of cognitive-behavioral group therapy plus pharmacotherapy has been stated to be more effective and tolerable than pharmacotherapy alone or in conjunction with ECT [31].

Overall, ECT is a safe, well-tolerated treatment that provides a substantial long-term benefit and relapse prevention for a meaningful proportion of patients with severe MDD [32]. Even if a considerable proportion of patients experiences relapse, ECT remains one of the most effective antidepressant therapies [33].

\section{Volumetric and Functional Brain Changes after ECT}

Significant volume increases after ECT that correlated with clinical improvement and might indicate that neurotrophic effects could be a part of the ECT mechanism of action were found in the anterior cingulate cortex (ACC) [34]. Moreover, a significant volume increase in both the hippocampus and the amygdala has been observed after ECT [35-38]. Surprisingly, even though the number of ECT sessions and the electrode placement influenced the extent and laterality of the hippocampal volume increase, no association with clinical outcome has been observed [39]. Similarly, an increase in temporomesial gray matter volume, mainly in the amygdala and the hippocampus, was not correlated with clinical change [40].

Brain volume might also be used as a prognostic biomarker. Accordingly, recent research has reported that a larger ACC volume prior to ECT is linked to treatment success [41]. Looking at limbic brain areas, it has been observed that larger pretreatment amygdala volume predicts better ECT response, whereby left amygdala volume seems to have a greater predictive value than right amygdala volume. Hippocampal volume on the other hand shows no independent predictive value [42].

Changes in resting-state network connectivity, referring to temporal correlating activity fluctuations between neuronal units, have been shown to interact with ECT treatment response. Dorsomedial prefrontal areas as well as ACC resting-state networks have been found to possibly predict the treatment outcome for individual patients [43]. A region in the medial prefrontal cortex defined as the dorsal nexus (DN) shows increased depression-associated functional connectivity (FC) with other networks implicated in different aspects of MDD [44]. Hence, it was suggested that reducing the increased connectivity of the DN might play a critical role in reducing the depressive symptomatology and thus represents a potential thera- peutic target. This hypothesis is supported by recent findings in healthy subjects showing that also ketamine decreases the FC of the DN $[45,46]$. A decreased FC between the DN and prefrontal areas such as the dorsolateral prefrontal cortex (DLPFC) might reflect restored aspects of emotional functioning while simultaneously contributing to the cognitive side effects of ECT [47].

Among the most consistent findings in depressive patients are alterations in resting state functional activation and connectivity in the pregenual ACC (pgACC), a region relevant for emotional processing and the establishment of mood states [48]. The pgACC is part of the default mode network [49], where activation is typically suppressed during the performance of cognitive or emotional tasks. The projection of the pgACC to the amygdala forms an important affective neurocircuitry for mood regulation since it allows for downregulation of the amygdala [50]. Overactivation of this affective processing network, in combination with a failing modulatory influence from prefrontal areas, may also contribute to the negative affective bias in MDD $[51,52]$. Depressed patients show greater responses to negative stimuli in the amygdala [53], while reductions in pathologically exaggerate amygdala activation $[54,55]$ and changes in FC between pgACC and the amygdala [56] have been linked to psychopharmacological treatment. Successful ECT has been associated with decreased cerebral blood flow and glucose metabolism in the ACC and amygdala [57, 58].

Testing early versus later ECT effects on the FC might be a feasible way to detect clinical predictors. Thereby, evidence indicates that an early intralimbic FC decrease predicts a later increase in the limbic-prefrontal FC, which in turn predicts the ECT response [59]. Along those lines, future studies might focus on restoration of dysfunctional activation and connectivity patterns within and between prefrontal-limbic circuits, as these might potentially serve as treatment predictors $[60,61]$.

\section{Changes in Neurotransmission after ECT}

Data from preclinical and clinical investigations suggests a key role of glutamate ( $\mathrm{Glu}$ ) in the pathophysiology of depression [62]. There is converging evidence for reduced levels of Glu and glutamine (Gln) in the pgACC [63, 64] and unchanged left DLPFC Glu concentrations [65, 66]. A reduced negative BOLD response during emotional processing in the pgACC has been related to reduced 
Gln concentrations in this region and might be particularly pronounced in highly anhedonic patients [63].

ECT leads to alterations of glutamatergic neurotransmission, which seem to be crucially involved in its antidepressant efficacy $[7,67]$. While some studies have reported increased Glx levels in the DLPFC and the ACC $[67,68]$ after ECT, others could not replicate these findings [66]. This might be due to the fact that the authors distinguished between Glu and Gln concentrations rather than using Glx, i.e., the combined values of these neurotransmitters.

Similarly conflicting results have been reported with regard to the hippocampus, where one recent study reported an association between hippocampal Glx increase and ECT response in treatment-resistant depression patients [69], although these results could not be confirmed by another report investigating uni- and bipolar patients with severe depression [38]. Altogether, glutamatergic brain metabolism emerges as an essential component in ECT efficacy but discrepancies in findings remain regarding the exact mechanism.

Also, diminished $\gamma$-aminobutyric acid (GABA) levels in the CSF and plasma, as well as a decreased GABA concentration in the frontal cortex, have been reported in MDD [70]. Accordingly, increased serum levels as well as occipital GABA concentrations have been observed after ECT $[60,61]$.

A growing body of evidence indicates that the ECT antidepressant response is also influenced by the 2 major amine systems associated with affective disorders, i.e., dopamine and serotonin [7]. Recent animal studies have indicated an increase in D2 receptor binding and dopamine-induced synaptic potentiation after ECT [71, 72]. Corroborating genetic and imaging data from human studies on ECT effects have reported increased serotonergic and mesocorticolimbic dopaminergic neurotransmission on various levels, starting from release over receptor binding up to signal transmission [7]. Also plasma (not only brain serotonin levels) has been reported to be increased after ECT [73].

As the different neurotransmitter systems involved in the antidepressant efficacy of ECT are interconnected via a complex network of signal transducing pathways, future studies could greatly benefit from more longitudinal multimodal designs involving measurement of different neurotransmission systems simultaneously.

Table 1 gives an extensive overview of neuroimaging studies on ECT effects.

\section{Effects of ECT on Inflammatory Processes}

Inflammatory cytokines are of growing interest in depression research, as a significant subgroup of patients with mood disorders exhibits increased inflammation that is supposed to impact Glu metabolism. MDD patients show increased levels of cytokines such as IL-6, IL$1 \beta$, TNF- $\alpha$, and CRP as well as a higher neutrophil/lymphocyte ratio. Bipolar patients show an additional increase in the platelet/lymphocyte ratio by which means these markers can be useful detectors of affective disorder related inflammation $[74,75]$. Strikingly, a third of the depressive patient population shows increased cytokine levels even in the absence of a medical illness. Depression is more closely associated with inflammatory diseases than with noninflammatory ones and a higher baseline inflammation has been linked to a decreased antidepressant treatment response [76]. On the other hand, lowgrade inflammation at baseline predicts a better ECT response in old patients [77], and this it is unclear whether this link exists for all ages.

The application of ECT in turn has been observed to first result in a transient immune activation, whereby repeated treatment rather induces long-term downregulation of the immune system [78]. Specifically, clinical improvement during ECT is accompanied by a gradual and significant decline in TNF- $\alpha$, eventually reaching levels comparable with those in healthy controls. This decline could not be observed in depressed patients without ECT, who showed elevated TNF- $\alpha$ levels throughout the study period [79]. Inflammatory processes impact the majority of the mechanisms in Glu neurotransmission, including multiple cellular effects for instance on astrocytes and microglia, mediating Glu release as well as reuptake mechanisms [80]. This might indicate that inflammation can also serve as a biomarker for an altered Glu metabolism in depression as it may represent a pathophysiological pathway by which inflammation has an impact on the brain to influence behavior [81]. Glu released by astrocytes has preferential access to NMDA receptors that in turn decrease brainderived neurotrophic factor (BDNF) and increase excitotoxicity $[82,83]$. The result might be a decrease in neuroplasticity and neurogenesis that contributes to the loss of function and volume particularly in the prefrontal cortex [75].

In an animal model, electroconvulsive shocks but not pharmacological treatment normalized both the depressive-like behavioral impairments and the BDNF-related molecular alterations [84]. In patients, several studies

Neuropsychobiology 2020;79:408-416 DOI: $10.1159 / 000505553$ 
Table 1. Overview of neuroimaging studies on ECT effects

\begin{tabular}{|c|c|c|c|c|c|}
\hline Study & $\begin{array}{l}\text { Subjects, } \\
n\end{array}$ & Diagnosis & Study design & $\begin{array}{l}\text { Rating } \\
\text { scales }\end{array}$ & Main result \\
\hline $\begin{array}{l}\text { Ota et al. } \\
{[34]}\end{array}$ & 15 & MDD & $\begin{array}{l}\text { sMRI before and after ECT for GMV } \\
\text { comparison }\end{array}$ & HAMD & $\begin{array}{l}\text { GMV increase in the medial and inferior } \\
\text { temporal cortices and the right ACC } \\
\text { correlating with clinical response }\end{array}$ \\
\hline $\begin{array}{l}\text { Sartorius et al. } \\
{[35]}\end{array}$ & 18 & MDD & $\begin{array}{l}\text { sMRI before and after ECT for GMV } \\
\text { comparison }\end{array}$ & HAMD & $\begin{array}{l}\text { GMV increase in the temporal lobe, the } \\
\text { hippocampus, and the amygdala following } \\
\text { ECT; no correlation of GMV with clinical } \\
\text { outcome }\end{array}$ \\
\hline $\begin{array}{l}\text { Tendolkar et al. } \\
\text { [36] }\end{array}$ & 15 & MDD & $\begin{array}{l}\text { sMRI before and after ECT analyzing } \\
\text { hippocampus/amygdala volume }\end{array}$ & HAMD & $\begin{array}{l}\text { Hippocampus and amygdala volume increase } \\
\text { following ECT }\end{array}$ \\
\hline $\begin{array}{l}\text { Dukart et al. } \\
\text { [37] }\end{array}$ & 19 vs. 15 & $\begin{array}{l}\text { MDD and } \\
\text { BD }\end{array}$ & $\begin{array}{l}\text { Longitudinal sMRI at } 3 \text { different ECT time } \\
\text { points (before and } 3 \text { and } 6 \text { months after), } \\
\text { examining local anatomical effects attributable } \\
\text { to ECT in patients vs. controls }\end{array}$ & HAMD & $\begin{array}{l}\text { GMV increase following ECT only in the right } \\
\text { hemisphere, restricted to the hippocampus, the } \\
\text { amygdala, the anterior temporal pole, the } \\
\text { insula, and the subgenual cortex }\end{array}$ \\
\hline $\begin{array}{l}\text { Jorgensen et al. } \\
\text { [38] }\end{array}$ & 19 & MDD & $\begin{array}{l}\text { Longitudinal sMRI, DTI, and MRS at } 3 \text { time } \\
\text { points over the course of ECT to investigate } \\
\text { volume, diffusivity, and metabolite changes in } \\
\text { the hippocampus and other brain regions over } \\
\text { the course of ECT }\end{array}$ & HAMD & $\begin{array}{l}\text { Hippocampal and amygdala volume increase; } \\
\text { DLPFC volume decrease; DTI revealed a } \\
\text { reduced anisotropy and diffusivity of the } \\
\text { hippocampus following ECT; no ECT-related } \\
\text { brain metabolite changes; no imaging measures } \\
\text { correlated with clinical outcome }\end{array}$ \\
\hline $\begin{array}{l}\text { Oltedal et al. } \\
\text { [39] }\end{array}$ & 281 & MDD & $\begin{array}{l}\text { sMRI before and after ECT examining } \\
\text { hippocampal volume changes related to the } \\
\text { ECT dosage in patients vs. healthy controls }\end{array}$ & $\begin{array}{l}\text { MADRS + } \\
\text { equated } \\
\text { HAMD }\end{array}$ & $\begin{array}{l}\text { Number of ECT and electrode placement } \\
\text { impact the extent and laterality of hippocampal } \\
\text { enlargement; no correlation with clinical } \\
\text { outcome }\end{array}$ \\
\hline $\begin{array}{l}\text { Sartorius et al. } \\
{[40]}\end{array}$ & 92 & MDD & $\begin{array}{l}\text { sMRI before and after ECT to investigate } \\
\text { GMV changes in patients vs. healthy controls }\end{array}$ & $\begin{array}{l}\text { No rating } \\
\text { scale }\end{array}$ & $\begin{array}{l}\text { Longitudinal GMV increase occurs in the } \\
\text { temporal lobe regions following ECT; within } \\
\text { the specific region of interest, sign increases of } \\
\text { GMV in the hippocampus and the amygdala; } \\
\text { no correlation with clinical outcome }\end{array}$ \\
\hline $\begin{array}{l}\text { Redlich et al. } \\
{[41]}\end{array}$ & 24 vs. 23 & MDD & $\begin{array}{l}\text { sMRI obtained before and after ECT, about } \\
6 \text { weeks apart. Samples of ECT and medicated } \\
\text { MDD patients compared to healthy controls }\end{array}$ & HAMD & $\begin{array}{l}\text { A larger pretreatment subgenual cingulate } \\
\text { volume is linked to ECT response }\end{array}$ \\
\hline $\begin{array}{l}\text { Ten Doesschate } \\
\text { et al. [42] }\end{array}$ & 53 & MDD & $\begin{array}{l}\text { sMRI before ECT examining the predictive } \\
\text { value of amygdala and hippocampal volumes } \\
\text { for ECT efficacy }\end{array}$ & MADRS & $\begin{array}{l}\text { A larger pretreatment amygdala volume } \\
\text { predicts more effective ECT }\end{array}$ \\
\hline $\begin{array}{l}\text { Van Waarde } \\
\text { et al. [43] }\end{array}$ & 45 & MDD & $\begin{array}{l}\text { rsfMRI before ECT investigating whether } \\
\text { rs FC can predict treatment outcomes for } \\
\text { individual patients }\end{array}$ & MADRS & $\begin{array}{l}\text { DMPFC or ACC FC before ECT predicts MDD } \\
\text { recovery with high sensitivity rates }\end{array}$ \\
\hline $\begin{array}{l}\text { Perrin et al. } \\
{[47]}\end{array}$ & 9 & MDD & fMRI before and after ECT examining FC & MADRS & $\begin{array}{l}\text { FC decrease in the left DLPFC correlating with } \\
\text { clinical outcome }\end{array}$ \\
\hline $\begin{array}{l}\text { Beall et al. } \\
{[52]}\end{array}$ & 6 & MDD & $\begin{array}{l}\text { rsfMRI and fMRI during an affective working } \\
\text { memory task before and after ECT examining } \\
\text { ECT-induced cortical activation patterns }\end{array}$ & HAMD & $\begin{array}{l}\text { An orbitofrontal activity decrease is associated } \\
\text { with ECT response. FC increase of ACC to the } \\
\text { right DLPFC and PCC before ECT }\end{array}$ \\
\hline $\begin{array}{l}\text { Redlich et al. } \\
{[54]}\end{array}$ & 24 vs. 23 & MDD & $\begin{array}{l}\text { fMRI during processing of emotional faces } \\
\text { obtained before and after ECT, about } 6 \text { weeks } \\
\text { apart. Samples of ECT and medicated MDD } \\
\text { patients compared to healthy controls }\end{array}$ & HAMD & $\begin{array}{l}\text { A decrease in amygdala activity to sad faces is } \\
\text { associated with clinical improvement in the } \\
\text { ECT sample }\end{array}$ \\
\hline $\begin{array}{l}\text { Nobler et al. } \\
{[57]}\end{array}$ & 10 & MDD & $\begin{array}{l}\text { PET before and after ECT examining regional } \\
\text { cerebral metabolic rate for glucose }\end{array}$ & HAMD & $\begin{array}{l}\text { Decreased regional cerebral glucose } \\
\text { metabolism after ECT in the frontal and } \\
\text { parietal cortex, the ACC, the PCC, and the left } \\
\text { temporal cortex }\end{array}$ \\
\hline
\end{tabular}


Table 1 (continued)

\begin{tabular}{llllll}
\hline Study & $\begin{array}{l}\text { Subjects, } \\
n\end{array}$ & Diagnosis & Study design & $\begin{array}{l}\text { Rating } \\
\text { scales }\end{array}$ & Main result \\
\hline $\begin{array}{l}\text { Segawa et al. } \\
{[58]}\end{array}$ & 10 & MDD & $\begin{array}{l}\text { PET before and after ECT examining changes } \\
\text { in rCBF }\end{array}$ & HAMD & $\begin{array}{l}\text { rCBF in the left frontopolar gyrus, the left } \\
\text { amygdala, the globus pallidus, the nucleus } \\
\text { accumbens, and the left superior temporal } \\
\text { gyrus correlates with clinical response }\end{array}$
\end{tabular}

Cano et al. $15 \quad$ MDD rsfMR longitudinal intralimbic and limbic-

[59] prefrontal network connectivity study at 4 time points over the course of ECT in patients vs. healthy controls

\begin{tabular}{lccl}
\hline $\begin{array}{l}\text { Sanacora et al. } \\
{[61]}\end{array}$ & 8 & MDD & $\begin{array}{l}\text { MRS before and after ECT to examine cortical } \\
\text { GABA concentrations }\end{array}$ \\
\hline $\begin{array}{l}\text { Merkl et al. } \\
{[66]}\end{array}$ & 25 & MDD & $\begin{array}{l}\text { MRS before and after ECT to determine } \\
\text { different metabolite concentrations in patients } \\
\text { vs. healthy controls }\end{array}$
\end{tabular}
decrease predicts a later increase in the limbicprefrontal FC, which predicts clinical improvement at the end of the ECT course

AMD Incease in the occipital cortex GABA concentration following ECT

HAMD Baseline Glu and NAA levels are decreased in the cingulum of MDD patients; a high Glu level at baseline predicts a greater treatment response; responders show increased NAA levels after ECT and decreased NAA levels in the left DLPFC

\begin{tabular}{|c|c|c|c|c|c|}
\hline $\begin{array}{l}\text { Pfleiderer et al. } \\
\text { [67] }\end{array}$ & 17 & MDD & $\begin{array}{l}\text { MRS before and after ECT to assess the effect } \\
\text { of successful ECT on Glx levels in the ACC in } \\
\text { patients vs. healthy controls }\end{array}$ & MADRS & $\begin{array}{l}\text { MDD patients exhibit reduced Glx levels in the } \\
\text { left ACC that normalize in ECT responders } \\
\text { until they no longer differ from age-matched } \\
\text { controls }\end{array}$ \\
\hline
\end{tabular}

sMRI, structural magnetic resonance GMV, gray matter volume; HAMD, Hamilton Rating Scale for Depression; GM, gray matter; BD, bipolar disorder; DTI, diffusion tensor imaging; MRS, magnetic resonance spectroscopy; MADRS, Montgomery-Asberg Depression Rating Scale; rsfMRI, resting-state functional magnetic resonance imaging; rs, resting state; FC, functional connectivity; DMPFC, dorsomedial prefrontal cortex; fMRI, functional magnetic resonance imaging; PCC, posterior prefrontal cortex; PET, position emission tomography; rCBF, regional cerebral blood flow; NAA, N-acetyl-aspartate; MTL, medial temporal lobe.

have observed increased serum or plasma BDNF levels after ECT [85], whereas others have found unaltered or decreased levels [86]. The difference in outcomes may be due to the fact that increases in peripheral BDNF levels may only reach their maximum 1 week to 1 month after the completion of ECT [87].

An investigation of the association of cytokine levels with Glu concentrations in distinct brain regions at several time points would help to elucidate whether inflammation might serve as a biomarker for altered Glu metabolism in MDD, with changes in cytokine levels associated with corresponding alterations in Glu concentrations reflecting or even predicting an ECT response.

\section{Summary and Outlook}

ECT is still one of the most potent and rapidly acting treatments for MDD. However, the efficacy and cognitive side effects of ECT seem to be influenced by parameters such as the positioning of electrodes, pulse width, and electrical dosage. While findings are still conflicting and far from conclusive, it seems that ECT exerts its antidepressant effect through its impact on regional brain structure and function via different neurotransmitter systems, inflammatory processes, and neurogenesis. With regard to brain structure, volume increases in the ACC, the amygdala, and the hippocampus after ECT are of particular research interest; however, these increases are not nec- 
essarily linked to clinical improvement. On the other hand, the pretreatment volume of the ACC and the amygdala has been linked to the ECT antidepressant response. Changes in functional activation and connectivity associated with ECT mainly concern key components of prefrontal-limbic circuits, such as the ACC, the dorsomedial and lateral prefrontal cortex, and the amygdala. Recent evidence indicates that early versus later ECT effects on functional connectivity might serve as clinical predictors. Glutamatergic neurotransmission plays a critical role in the pathophysiology of MDD, and changes in prefrontal and hippocampal Glu concentrations have been related to the ECT antidepressant response, while the regional and temporal specificity and the predictive value of these changes remain unclear. Furthermore, the effects of ECT on GABA, serotonine, and dopamine have been reported. Finally, increased levels of cytokines have been described in MDD patients and recent evidence suggests that inflammation is linked to altered glutamatergic neurotransmission. Clinical improvement during ECT is accompanied by a significant decline in inflammatory markers.

In order to better understand the antidepressant effects of ECT, future studies should apply multimodal approaches and investigate markers of neural activity and connectivity, neurochemistry, and inflammation simultaneously and at multiple time points. This might allow determination of which cognitive, neuronal, and immu- nological alterations are crucial for an antidepressant response and might be used for response prediction. More generally, this would also shed more light on the pathophysiological causes of MDD and the mechanisms of action of an effective treatment.

\section{Statement of Ethics}

The authors have no ethical conflicts to declare.

\section{Disclosure Statement}

The authors have no conflicts of interests to declare.

\section{Funding Sources}

This work was supported by the Deutsche Forschungsgemeinschaft (DFG; 389184626).

\section{Author Contributions}

A.S. and F.N.K. wrote this paper. M.B. contributed to the section on clinical data. S.G. contributed to the section on neurobiological data and cowrote this paper.

\section{References}

1 Kessler RC, Berglund P, Demler O, Jin R, Koretz D, Merikangas KR, et al.; National Comorbidity Survey Replication. The epidemiology of major depressive disorder: results from the National Comorbidity Survey Replication (NCS-R). JAMA. 2003 Jun;289(23):3095-105.

2 Moussavi S, Chatterji S, Verdes E, Tandon A, Patel V, Ustun B. Depression, chronic diseases, and decrements in health: results from the World Health Surveys. Lancet. 2007 Sep; 370(9590):851-8.

3 Friedrich MJ. Depression is the leading cause of disability around the world. JAMA. 2017 Apr;317(15):1517-1517.

4 Lancet T; The Lancet. Life, death, and disability in 2016. Lancet. 2017 Sep;390(10100):1083.

5 Bauer M, Pfennig A, Severus E, Whybrow PC, Angst J, Möller HJ; World Federation of Societies of Biological Psychiatry. Task Force on Unipolar Depressive Disorders. World Federation of Societies of Biological Psychiatry (WFSBP) guidelines for biological treatment of unipolar depressive disorders, part 1: update 2013 on the acute and continuation treatment of unipolar depressive disorders. World J Biol Psychiatry. 2013 Jul;14(5):334-85.
6 Rush G, O’Donovan A, Nagle L, Conway C, McCrohan A, O'Farrelly C, et al. Alteration of immune markers in a group of melancholic depressed patients and their response to electroconvulsive therapy. J Affect Disord. 2016 Nov;205:60-8.

7 Baldinger P, Lotan A, Frey R, Kasper S, Lerer B, Lanzenberger R. Neurotransmitters and electroconvulsive therapy. J ECT. 2014 Jun; 30(2):116-21.

8 Merkl A, Heuser I, Bajbouj M. Antidepressant electroconvulsive therapy: mechanism of action, recent advances and limitations. Exp Neurol. 2009 Sep;219(1):20-6.

9 Luchini F, Medda P, Mariani MG, Mauri M, Toni C, Perugi G. Electroconvulsive therapy in catatonic patients: efficacy and predictors of response. World J Psychiatry. 2015 Jun; 5(2):182-92.

10 Perugi G, Medda P, Toni C, Mariani MG, Socci $\mathrm{C}$, Mauri M. The role of electroconvulsive therapy (ECT) in bipolar disorder: effectiveness in 522 patients with bipolar depression, mixed-state, mania and catatonic features. Curr Neuropharmacol. 2017 Apr;15(3):35971.
11 Zervas IM, Theleritis C, Soldatos CR. Using ECT in schizophrenia: a review from a clinical perspective. World J Biol Psychiatry. 2012 Feb;13(2):96-105.

12 Leiknes KA, Jarosh-von Schweder L, Høie B. Contemporary use and practice of electroconvulsive therapy worldwide. Brain Behav. 2012 May;2(3):283-344.

13 Ma Y, Rosenheck R, Fan N, He H. Rates and patient characteristics of electroconvulsive therapy in china and comparisons with the united states. J ECT. 2019 Dec;35(4):251-7.

14 Haq AU, Sitzmann AF, Goldman ML, Maixner DF, Mickey BJ. Response of depression to electroconvulsive therapy: a metaanalysis of clinical predictors. J Clin Psychiatry. 2015 Oct; 76(10):1374-84.

15 Bauer M, Bschor T, Pfennig A, Whybrow PC, Angst J, Versiani M, et al.; WFSBP Task Force on Unipolar Depressive Disorders; WFSBP Task Force on Unipolar Depres. World Federation of Societies of Biological Psychiatry (WFSBP) Guidelines for biological treatment of unipolar depressive disorders in primary care. World J Biol Psychiatry. 2007;8(2):67104. 
16 Medda P, Toni C, Mariani MG, De Simone L, Mauri M, Perugi G. Electroconvulsive therapy in 197 patients with a severe, drug-resistant bipolar mixed state: treatment outcome and predictors of response. J Clin Psychiatry. 2015 Sep;76(9):1168-73.

17 Husain MM, Rush AJ, Fink M, Knapp R, Petrides G, Rummans T, et al. Speed of response and remission in major depressive disorder with acute electroconvulsive therapy (ECT): a Consortium for Research in ECT (CORE) report. J Clin Psychiatry. 2004 Apr;65(4):48591.

18 Neyazi A, Theilmann W, Brandt C, Rantamäki T, Matsui N, Rhein M, et al. P11 promoter methylation predicts the antidepressant effect of electroconvulsive therapy. Transl Psychiatry. 2018 Jan;8(1):25.

19 Lee HJ. Is advancing of circadian rhythm a reason for the rapid treatment effect of electroconvulsive therapy? Psychiatry Investig. 2018 Jul;15(7):655.

20 Devanand DP, Fitzsimons L, Prudic J, Sackeim HA. Subjective side effects during electroconvulsive therapy. Convuls Ther. 1995 Dec;11(4):232-40.

21 Semkovska M, McLoughlin DM. Objective cognitive performance associated with electroconvulsive therapy for depression: a systematic review and meta-analysis. Biol Psychiatry. 2010 Sep;68(6):568-77.

22 Maric NP, Stojanovic Z, Andric S, Soldatovic I, Dolic M, Spiric Z. The acute and mediumterm effects of treatment with electroconvulsive therapy on memory in patients with major depressive disorder. Psychol Med. 2016 Mar;46(4):797-806.

23 Masand PS, Gupta S. Long-term side effects of newer-generation antidepressants: SSRIS, venlafaxine, nefazodone, bupropion, and mirtazapine. Ann Clin Psychiatry. 2002 Sep; 14(3):175-82.

24 Bodnar A, Krzywotulski M, Lewandowska A, Chlopocka-Wozniak M, Bartkowska-Sniatkowska A, Michalak M, et al. Electroconvulsive therapy and cognitive functions in treatment-resistant depression. World J Biol Psychiatry. 2016;17(2):159-64.

25 Roepke S, Luborzewski A, Schindler F, Quante A, Anghelescu I, Heuser I, et al. Stimulus pulse-frequency-dependent efficacy and $\operatorname{cog}$ nitive adverse effects of ultrabrief-pulse electroconvulsive therapy in patients with major depression. J ECT. 2011 Jun;27(2):109-13.

26 Quante A, Luborzewski A, Brakemeier EL, Merkl A, Danker-Hopfe H, Bajbouj M. Effects of 3 different stimulus intensities of ultrabrief stimuli in right unilateral electroconvulsive therapy in major depression: a randomized, double-blind pilot study. J Psychiatr Res. 2011 Feb;45(2):174-8.

27 Tor PC, Bautovich A, Wang MJ, Martin D, Harvey SB, Loo C. A Systematic review and meta-analysis of brief versus ultrabrief right unilateral electroconvulsive therapy for depression. J Clin Psychiatry. 2015 Sep; 76(9):e1092-8.
28 Kellner CH, Knapp RG, Petrides G, Rummans TA, Husain MM, Rasmussen $\mathrm{K}$, et al. Continuation electroconvulsive therapy vs pharmacotherapy for relapse prevention in major depression: a multisite study from the Consortium for Research in Electroconvulsive Therapy (CORE). Arch Gen Psychiatry. 2006 Dec;63(12):1337-44.

29 Antunes PB, Fleck MP. Remission of symptoms in patients with unipolar and bipolar depression submitted to electroconvulsive therapy. J ECT. 2009 Dec;25(4):291.

30 Elias A, Phutane VH, Clarke S, Prudic J. Electroconvulsive therapy in the continuation and maintenance treatment of depression: systematic review and meta-analyses. Aust N Z J Psychiatry. 2018 May;52(5):415-24.

31 Brakemeier EL, Merkl A, Wilbertz G, Quante A, Regen F, Bührsch N, et al. Cognitive-behavioral therapy as continuation treatment to sustain response after electroconvulsive therapy in depression: a randomized controlled trial. Biol Psychiatry. 2014 Aug;76(3):194-202.

32 Gazdag G, Ungvari GS. Electroconvulsive therapy: 80 years old and still going strong. World J Psychiatry. 2019 Jan;9(1):1-6.

33 George MS, Taylor JJ, Short B. Chapter 33 Treating the depressions with superficial brain stimulation methods. In: Lozano AM, Hallett M, editors. Handbook of Clinical Neurology. Elsevier; 2013. pp. 399-413.

34 Ota M, Noda T, Sato N, Okazaki M, Ishikawa $\mathrm{M}$, Hattori K, et al. Effect of electroconvulsive therapy on gray matter volume in major depressive disorder. J Affect Disord. 2015 Nov; 186:186-91.

35 Sartorius A, Demirakca T, Böhringer A, Clemm von Hohenberg C, Aksay SS, Bumb $\mathrm{JM}$, et al. Electroconvulsive therapy increases temporal gray matter volume and cortical thickness. Eur Neuropsychopharmacol. 2016 Mar;26(3):506-17.

36 Tendolkar I, van Beek M, van Oostrom I, Mulder M, Janzing J, Voshaar RO, et al. Electroconvulsive therapy increases hippocampal and amygdala volume in therapy refractory depression: a longitudinal pilot study. Psychiatry Res. 2013 Dec;214(3):197-203.

37 Dukart J, Regen F, Kherif F, Colla M, Bajbouj $\mathrm{M}$, Heuser I, et al. Electroconvulsive therapyinduced brain plasticity determines therapeutic outcome in mood disorders. Proc Natl Acad Sci USA. 2014 Jan;111(3):1156-61.

38 Jorgensen A, Magnusson P, Hanson LG, Kirkegaard T, Benveniste H, Lee H, et al. Regional brain volumes, diffusivity, and metabolite changes after electroconvulsive therapy for severe depression. Acta Psychiatr Scand. 2016 Feb;133(2):154-64.

39 Oltedal L, Narr KL, Abbott C, Anand A, Argyelan M, Bartsch $\mathrm{H}$, et al. Volume of the human hippocampus and clinical response following electroconvulsive therapy. Biol Psychiatry. 2018 Oct; 84(8):574-81.
40 Sartorius A, Demirakca T, Böhringer A, Clemm von Hohenberg C, Aksay SS, Bumb $\mathrm{JM}$, et al. Electroconvulsive therapy induced gray matter increase is not necessarily correlated with clinical data in depressed patients. Brain Stimul. 2019 Mar - Apr;12(2): $335-43$.

41 Redlich R, Opel N, Grotegerd D, Dohm K, Zaremba $\mathrm{D}$, Bürger $\mathrm{C}$, et al. Prediction of individual response to electroconvulsive therapy via machine learning on structural magnetic resonance imaging data. JAMA Psychiatry. 2016 Jun;73(6):557-64.

42 Ten Doesschate F, van Eijndhoven P, Tendolkar I, van Wingen GA, van Waarde JA. Pretreatment amygdala volume predicts electroconvulsive therapy response. Front Psychiatry. 2014 Nov;5:169.

43 Van Waarde JA, Scholte HS, van Oudheusden LJ, Verwey B, Denys D, van Wingen GA. A functional MRI marker may predict the outcome of electroconvulsive therapy in severe and treatment-resistant depression. Mol Psychiatry. 2015 May;20(5):609-14

44 Sheline YI, Price JL, Yan Z, Mintun MA. Resting-state functional MRI in depression unmasks increased connectivity between networks via the dorsal nexus. Proc Natl Acad Sci USA. 2010 Jun;107(24):11020-5.

45 Lehmann M, Seifritz E, Henning A, Walter M, Böker H, Scheidegger M, et al. Differential effects of rumination and distraction on ketamine induced modulation of resting state functional connectivity and reactivity of regions within the default-mode network. Soc Cogn Affect Neurosci. 2016 Aug;11(8):122735.

46 Cano M, Martínez-Zalacaín I, Bernabéu-Sanz Á, Contreras-Rodríguez O, Hernández-Ribas $\mathrm{R}$, Via $\mathrm{E}$, et al. Brain volumetric and metabolic correlates of electroconvulsive therapy for treatment-resistant depression: a longitudinal neuroimaging study. Transl Psychiatry. 2017 Feb;7(2):e1023.

47 Perrin JS, Merz S, Bennett DM, Currie J, Steele DJ, Reid IC, et al. Electroconvulsive therapy reduces frontal cortical connectivity in severe depressive disorder. Proc Natl Acad Sci USA. 2012 Apr;109(14):5464-8.

48 Pizzagalli DA. Frontocingulate dysfunction in depression: toward biomarkers of treatment response. Neuropsychopharmacology. 2011 Jan;36(1):183-206.

49 Raichle ME, MacLeod AM, Snyder AZ, Powers WJ, Gusnard DA, Shulman GL. A default mode of brain function. Proc Natl Acad Sci USA. 2001 Jan;98(2):676-82.

50 Drevets WC. Neuroimaging abnormalities in the amygdala in mood disorders. Ann N Y Acad Sci. 2003 Apr;985(1):420-44.

51 Phillips ML, Drevets WC, Rauch SL, Lane R. Neurobiology of emotion perception II: implications for major psychiatric disorders. Biol Psychiatry. 2003 Sep;54(5):515-28. 
52 Beall EB, Malone DA, Dale RM, Muzina DJ, Koenig KA, Bhattacharrya PK, et al. Effects of electroconvulsive therapy on brain functional activation and connectivity in depression. J ECT. 2012 Dec;28(4):234-41.

53 Hamilton JP, Etkin A, Furman DJ, Lemus MG, Johnson RF, Gotlib IH. Functional neuroimaging of major depressive disorder: a meta-analysis and new integration of base line activation and neural response data. Am J Psychiatry. 2012 Jul;169(7):693-703.

54 Redlich R, Bürger C, Dohm K, Grotegerd D, Opel N, Zaremba D, et al. Effects of electroconvulsive therapy on amygdala function in major depression - a longitudinal functional magnetic resonance imaging study. Psychol Med. 2017 Sep;47(12):2166-76.

55 Delaveau P, Jabourian M, Lemogne C, Guionnet S, Bergouignan L, Fossati P. Brain effects of antidepressants in major depression: a meta-analysis of emotional processing studies. J Affect Disord. 2011 Apr;130(1-2):66-74.

56 McCabe C, Mishor Z. Antidepressant medications reduce subcortical-cortical restingstate functional connectivity in healthy volunteers. Neuroimage. 2011 Aug;57(4):131723.

57 Nobler MS, Oquendo MA, Kegeles LS, Malone KM, Campbell CC, Sackeim HA, et al. Decreased regional brain metabolism after ect. Am J Psychiatry. 2001 Feb;158(2):305-8.

58 Segawa K, Azuma H, Sato K, Yasuda T, Arahata $\mathrm{K}$, Otsuki $\mathrm{K}$, et al. Regional cerebral blood flow changes in depression after electroconvulsive therapy. Psychiatry Res. 2006 Oct:147(2-3):135-43.

59 Cano M, Cardoner N, Urretavizcaya M, Martínez-Zalacaín I, Goldberg X, Via E, et al. Modulation of limbic and prefrontal connectivity by electroconvulsive therapy in treatment-resistant depression: a preliminary study. Brain Stimul. 2016 Jan-Feb;9(1):65-71.

60 Esel E, Kose K, Hacimusalar Y, Ozsoy S, Kula $\mathrm{M}$, Candan Z, et al. The effects of electroconvulsive therapy on GABAergic function in major depressive patients. J ECT. 2008 Sep; 24(3):224-8.

61 Sanacora G, Mason GF, Rothman DL, Hyder F, Ciarcia JJ, Ostroff RB, et al. Increased cortical GABA concentrations in depressed patients receiving ECT. Am J Psychiatry. 2003 Mar;160(3):577-9.

62 Sanacora G, Treccani G, Popoli M. Towards a glutamate hypothesis of depression: an emerging frontier of neuropsychopharmacology for mood disorders. Neuropharmacology. 2012 Jan;62(1):63-77.

63 Walter M, Henning A, Grimm S, Schulte RF, Beck J, Dydak U, et al. The relationship between aberrant neuronal activation in the pregenual anterior cingulate, altered glutamatergic metabolism, and anhedonia in major depression. Arch Gen Psychiatry. 2009 May; 66(5):478-86.

64 Arnone D, Mumuni AN, Jauhar S, Condon B, Cavanagh J. Indirect evidence of selective glial involvement in glutamate-based mechanisms of mood regulation in depression: meta-analysis of absolute prefrontal neuro-metabolic concentrations. Eur Neuropsychopharmacol. 2015 Aug;25(8):1109-17.

65 Grimm S, Ernst J, Boesiger P, Schuepbach D, Boeker H, Northoff G. Reduced negative BOLD responses in the default-mode network and increased self-focus in depression. World J Biol Psychiatry. 2011 Dec;12(8):62737.

66 Merkl A, Schubert F, Quante A, Luborzewski A, Brakemeier EL, Grimm S, et al. Abnormal cingulate and prefrontal cortical neurochemistry in major depression after electroconvulsive therapy. Biol Psychiatry. 2011 Apr;69(8): 772-9.

67 Pfleiderer B, Michael N, Erfurth A, Ohrmann P, Hohmann U, Wolgast M, et al. Effective electroconvulsive therapy reverses glutamate/ glutamine deficit in the left anterior cingulum of unipolar depressed patients. Psychiatry Res. 2003 Apr;122(3):185-92.

68 Michael N, Erfurth A, Ohrmann P, Arolt V, Heindel W, Pfleiderer B. Metabolic changes within the left dorsolateral prefrontal cortex occurring with electroconvulsive therapy in patients with treatment resistant unipolar depression. Psychol Med. 2003 Oct;33(7):127784.

69 Kobayashi K, Imoto Y, Yamamoto F, Kawasaki M, Ueno M, Segi-Nishida E, et al. Rapid and lasting enhancement of dopaminergic modulation at the hippocampal mossy fiber synapse by electroconvulsive treatment. J Neurophysiol. 2017 Jan;117(1):284-9.

70 Lloyd KG, Morselli PL, Bartholini G. GABA and affective disorders. Med Biol. 1987;65(23):159-65.

71 Hasani PA, Moghadam FM, Mokhtaree M, Nazer M. Effect of electroconvulsive therapy on serum serotonin level in patients with treatment resistant major depressive disorder. J Evol Med Dent Sci. 2019 Aug;8(16): 1283-6.

72 Landau AM, Alstrup AK, Audrain H, Jakobsen S, Simonsen M, Møller A, et al. Elevated dopamine D1 receptor availability in striatum of Göttingen minipigs after electroconvulsive therapy. J Cereb Blood Flow Metab. 2018 May;38(5):881-7.

73 Hasani PA, Moghadam FM, Mokhtaree M, Nazer M. Effect of electroconvulsive therapy on serum serotonin level in patients with treatment resistant major depressive disorder. J Evol Med Dent Sci. 2019 Aug;8(16): 1283-6.

74 Mazza MG, Lucchi S, Tringali AG, Rossetti A, Botti ER, Clerici M. Neutrophil/lymphocyte ratio and platelet/lymphocyte ratio in mood disorders: A meta-analysis. Prog Neuropsychopharmacol Biol Psychiatry. $2018 \mathrm{Jun} ; 84 \mathrm{Pt}$ A:229-36.

75 Gold PW. The organization of the stress system and its dysregulation in depressive illness. Mol Psychiatry. 2015 Feb;20(1):32-47.

76 Leighton SP, Nerurkar L, Krishnadas R, Johnman C, Graham GJ, Cavanagh J. Chemokines in depression in health and in inflammatory illness: a systematic review and meta-analysis. Mol Psychiatry. 2018 Jan;23(1):48-58.

77 Carlier A, Berkhof JG, Rozing M, Bouckaert F, Sienaert P, Eikelenboom P, et al. Inflammation and remission in older patients with depression treated with electroconvulsive therapy; findings from the MODECT study. J Affect Disord. 2019 Sep;256:509-16.

78 Guloksuz S, Rutten BP, Arts B, van Os J, Kenis $\mathrm{G}$. The immune system and electroconvulsive therapy for depression. J ECT. 2014 Jun;30(2): 132-7.

79 Hestad KA, Tønseth S, Støen CD, Ueland T, Aukrust P. Raised plasma levels of tumor necrosis factor alpha in patients with depression: normalization during electroconvulsive therapy. J ECT. 2003 Dec;19(4):1838.

80 Haroon E, Miller AH. Inflammation effects on brain glutamate in depression: mechanistic considerations and treatment implications. In: Dantzer R, Capuron L, editors. Inflammation-Associated Depression: Evidence, Mechanisms and Implications. Cham: Springer International Publishing; 2017. pp. 173-98.

81 Kruse JL, Congdon E, Olmstead R, Njau S, Breen EC, Narr KL, et al. Inflammation and improvement of depression following electroconvulsive therapy in treatment-resistant depression. J Clin Psychiatry. 2018 Mar/Apr; 79(2):17-23.

82 Miller AH, Maletic V, Raison CL. Inflammation and its discontents: the role of cytokines in the pathophysiology of major depression. Biol Psychiatry. 2009 May;65(9):732-41.

83 Hardingham GE, Bading H. Synaptic versus extrasynaptic NMDA receptor signalling: implications for neurodegenerative disorders. Nat Rev Neurosci. 2010 Oct;11(10):682-96.

84 Gersner R, Gal R, Levit O, Moshe H, Zangen A. Inherited behaviors, BDNF expression and response to treatment in a novel multifactorial rat model for depression. Int J Neuropsychopharmacol. 2014 Jun;17(6):945-55.

85 Okamoto T, Yoshimura R, Ikenouchi-Sugita A, Hori $\mathrm{H}$, Umene-Nakano W, Inoue $\mathrm{Y}$, et al. Efficacy of electroconvulsive therapy is associated with changing blood levels of homovanillic acid and brain-derived neurotrophic factor (BDNF) in refractory depressed patients: a pilot study. Prog Neuropsychopharmacol Biol Psychiatry. 2008 Jul;32(5):118590.

86 Lin CH, Chen MC, Lee WK, Chen CC, Huang $\mathrm{CH}$, Lane HY. Electroconvulsive therapy improves clinical manifestation with plasma BDNF levels unchanged in treatment-resistant depression patients. Neuropsychobiology. 2013;68(2):110-5.

87 Bumb JM, Aksay SS, Janke C, Kranaster L, Geisel O, Gass P, et al. Focus on ECT seizure quality: serum BDNF as a peripheral biomarker in depressed patients. Eur Arch Psychiatry Clin Neurosci. 2015 Apr;265(3):22732. 